\title{
A DESCRIÇÃO DE JESUS CRISTO COMO MA- GO NO DISCURSO VERDADEIRO CONTRA OS CRISTÃOS DE CELSO (II-III d.C.)
}

\section{THE PORTRAYAL OF JESUS CHRIST AS A MAGICIAN IN THE TRUE DISCOURSE AGAISNT THE CHRISTIANS OF CELSUS (II-III A.D.)}

Breno Teles Pereira ${ }^{1}$

Resumo: A partir de meados do II séc. d.C., alguns locais no Império Romano presenciaram perseguições - iniciadas primeiramente por cidadãos romanos - que resultaram em levas de execuções e martírios de cristãos. Com uma doutrina ainda em construção, mesclando teorias filosóficas grecorromanas e traços de originalidade cristã, o cristianismo se encontrava em processo de expansão, inclusive em meio às várias escolas filosóficas que se concentravam principalmente em Roma e Alexandria. Em provável resposta a isso, Celso escreve a obra Discurso Verdadeiro Contra os Cristãos, tratando de várias querelas que incluem a falta de originalidade do cristianismo, a quebra de raízes com o judaísmo e, alvo de nossa exposição, a descrição do fundador do cristianismo, Jesus Cristo, como um mago, almejando assim expor a hipótese de que a deslegitimação do líder desse movimento encaixava-se em um contexto de intolerância à magia.

Palavras-chave: Celso, Jesus Cristo, Império Romano, Cristianismo, Magia.

Abstract: Beginning in the middle of II century A.D., some places in the Roman Empire witnessed persecutions - firstly started by roman citizens - that resulted in waves of executions and Christian martyrdom. With a doctrine still in development, mixing philosophical Greco-

\footnotetext{
${ }^{1}$ Graduando de História na Universidade Federal de Goiás, Faculdade de História; bolsista PIBIC com pesquisa em História Antiga.
} 
Roman theories and traits of Christian originality, Christianity found itself in an expansion process, even in the middle of the multiple philosophical schools that were focused mainly in Rome and Alexandria. Likely responding to this, Celsus writes his workTrue Discourse Against the Christians, dealing with various contests that includes the lack of originality of Christianity, the breaking of roots with Judaism and, object of our exposition, the portrayal of the founder of Christianity, Jesus Christ, as a magician, aiming therefore to show the hypothesis that the delegitimization of the leader of this movement fits in a context of intolerance to magic.

Keywords: Celsus, Jesus Christ, Roman Empire, Christianity, Magic.

Celso destaca-se como o primeiro polemista a compor um texto sistematizado contra os cristãos. As argumentações anteriores no I e II séc. d.C., que relegavam-se majoritariamente em acusações de imoralidade, seguindo o topos de que os cristãos participavam de seitas que banhavam-se em sangue de infantes e praticavam rituais orgíacos, são deixadas de lado pela crescente necessidade de se combater os mesmos em um âmbito mais profundo: o da doutrina. Infelizmente, sua obra se perdeu e, apenas no séc. XIX, através do Contra Celso de Orígenes, é que as tentativas de reconstrução da mesma iniciam-se. Isso é possível devido às citações literais de Orígenes que, ao tentar refutar os dizeres de Celso, percebe esse método como o mais apropriado para fazê-lo.

Antes de adentrarmos a especificidade da proposta, comecemos nossa exposição a partir dos dizeres de Orígenes em Contra Celso, para traçarmos o possível da biografia de Celso:

Por isso devo lamentar que alguém possa acreditar em Cristo com uma fé capaz de ser abalada por Celso, que se- 
quer vive a vida comum entre os homens, mas morreu há muito tempo [...] (ORÍGENES, Contra Celso, Prefácio, 4, grifo nosso).

Um fato a ser lembrado é que a obra foi solicitada a Orígenes por Ambrósio $^{2}$, patrístico contemporâneo do mesmo, que se interessava por sua perspectiva e por seus escritos já de grande proporção ${ }^{3}$ na época. Provavelmente, o conhecimento de quem foi Celso foi repassado brevemente por Ambrósio, deixando assim Orígenes à mercê de obras de contextos passados para reconstruir parte da vida de Celso. A primeira ideia exposta acima é a morte que ocorreu há tempos; tal frase é uma das hipóteses que levará estudiosos de Orígenes e Celso a especularem sobre a data de sua obra. Aprofundando sua pesquisa, Orígenes elenca alguns pensamentos; é o que notamos, em sequência, na seguinte explanação:

Reconhecemos aqui o epicureu de seus outros escritos; aqui, como sua acusação contra o cristianismo há de pare-

${ }^{2}$ Ambrósio de Alexandria (ca. 212 - ca. 250 d.C.) foi conhecido de Orígenes, primeiramente membro da seita valentiniana, posteriormente reconduzido à ortodoxia através de Orígenes. É devido a pedidos dele que Orígenes compôs o Contra Celso. Orígenes dedica a ele a Exortação ao Martírio, pois, Ambrósio foi perseguido sob Império de Maximino o Trácio (235 d.C.). Segundo Jerônimo, Ambrósio morre antes de Orígenes, porém, sua data de nascimento é especulada. Ver: CROUZEL, Henri. Ambrósio. In: DI BERARDINO, Angelo (org.). Dicionário Patrístico e de Antiguidades Cristãs. Petrópolis: Vozes \&Paulus, 2002. p. 83.

${ }^{3}$ Eusébio de Cesaréia elenca 2 mil livros de Orígenes, baseando-se em Jerônimo. Já o próprio Jerônimo coloca apenas 800 livros. Não podemos nos esquecer, claro, que livros para eles não significa o mesmo que para nós. Atualmente, o termo se pareceria mais com "capítulos". Ver: ORÍGENES. Contra Celso. Trad. Orlando dos Reis. São Paulo: Paulus, 2004. p. 17. 
cer mais plausível não professando as teses de Epicuro [...] Sabia bem que, declarando-se epicureu, não teria crédito nenhum em sua acusação contra aqueles que de algum modo admitem uma providência e imaginam um deus acima do universo. Mas ouvi dizer que existiram dois Celsos epicureus, um no império de Nero, e este, no império de Adriano e mais tarde. (ORÍGENES, Contra Celso, I, 8, grifo nosso)

A primeira hipótese apresentada aqui por Orígenes demonstra que sua leitura progressiva do Discurso Verdadeiro lhe dá uma noção de quem seria Celso. Tendo definido previamente que o autor seria epicureu, procura referência a "Celsos epicuristas" em épocas anteriores. Encontrando as duas possibilidades, dá continuidade às suas refutações. Como veremos, sua ideia será colocada em dúvida posteriormente no livro:

Vamos então discutir um pouco estes pontos, e provar que ele dissimula sua opinião epicuréia, ou talvez se diga que ele a abandonou por melhores doutrinas, ou mesmo, se poderia dizer, que ele é homônimo de Celso epicureu. (ORÍGENES,Contra Celso, IV, 54, grifo nosso)

É interessante perceber que com "melhores doutrinas" o autor possivelmente se refere à platônica; corroboramos essa alegação também com descrição de Orígenes no mesmo tópico, que escreve: "Na passagem de Celso que citei, que é uma paráfrase do Timeu ${ }^{4}$, encontramos certas expressões..." (ORÍGENES, Contra Celso, IV, 54).

${ }^{4}$ Obra de Platão (séc. IV a.C.). 
Deduz-se através de Orígenes, portanto, que: Celso está morto há muito tempo; é epicurista; possivelmente do Império de Adriano e adiante; provavelmente platônico. Assim, define-se superficialmente por intermédio de Orígenes e de nossa análise do Contra Celso as possibilidades de quem poderia ser Celso. Iniciemos as outras propostas, começando pelo século XIX.

Charles Bruhl, em uma tese brevíssima, provavelmente o primeiro trabalho específico sobre Celso, se baseia apenas na polêmica anticristã e tenta reconstruir o conhecimento sobre cristianismo do polemista. ${ }^{5} \mathrm{O}$ livro do autor, como descrito pelo título de um dos capítulos, tratará primariamente de um resumo da polêmica de Celso (BRUHL, 1844: 4). Após isso, adentra o conhecimento de Celso sobre o cristianismo, demonstrando algumas possíveis referências indiretas do autor sobre o Novo Testamento (BRUHL, 1844: 17). Posteriormente, analisa o provável motivo de Celso ao escrever seu Discurso Verdadeiro e suas características (BRUHL, 1844: 20, 24) - Bruhl (1844: 28) julga que Celso escreveu-o para defender a religião de seus compatriotas - e, ao fim, conclui seu trabalho dizendo que, por mais que a polêmica possa ser apreciada, não é possível compará-la à grandeza invencível do cristianismo na resposta de Orígenes. O autor, portanto, foca primariamente na obra em si, e não delonga nas possibilidades de quem foi Celso.

Cerca de 30 anos depois, Elisée Pelagaud escreve o trabalho subsequente ao de Bruhl - com referências no texto a ele; Pelagaud não

${ }^{5}$ São 36 páginas no total; a abordagem a Celso ainda era totalmente baseada na leitura direta da obra de Orígenes. Ver: BRUHL, Charles. La Polémique de Celse Contre le Christianisme. Strasbourg: Frédéric-Charles Heitz, 1844. 
ousa especular sobre as origens do autor, pois, sabe que são escassas de referências - e, devemos levar em consideração a falta de bibliografia sobre o tema em sua época. Aparentemente, como citado no livro, a reconstrução do Discurso Verdadeiro já estava em andamento, sendo feitas as primeiras ${ }^{6}$ tentativas pelo teólogo Karl Theodor Keim (1873) (PELAGAUD, 1878: XVII, XVIII) e, posteriormente, por Paul Koetschau (1899). Tal empreitada influenciou futuras traduções e análises sobre Celso no século XX e XXI.

Theodor Keim, em seu livro A Verdadeira Palavra de Celso ${ }^{7}$, é o fator principal de influência da maioria das diretrizes acadêmicas sobre o Discurso Verdadeiro no séc. XX; o autor defende veementemente que as afirmativas de Orígenes estavam corretas e que Celso deveria ser identificado com o amigo epicurista de Galeno e Luciano de Samósata, que, de acordo com Luciano, "estudou o assunto de magia e mágicos suficientemente, apresentando amplo material que colocaria juízo em quem quer que o lê-se" (Alexandre o Falso Profeta,I) ${ }^{8}$. Apesar do texto

\footnotetext{
${ }^{6} \mathrm{Na}$ realidade, antes de Keim possuíamos um trabalho mais amplo, de 1830, que possui excertos dos três anticristãos que mais tiveram repercussão: Celso, Porfírio e o Imperador Juliano. Não julgamos como a primeira tentativa, pois, não se trata de um trabalho sistemático de reconstrução de toda a obra de Celso, e sim de pequenas partes dela. Ver: CELSUS; POPHYRY; JULIAN. Arguments of Celsus, Porphyry, and the Emperor Julian, Against the Christians; also extracts from DiodorusSiculus, Josephus, and Tacitus, relating to the Jews. Trad. NathanielLardner. London: Thomas Rodd, 1830.

${ }^{7}$ Tradução nossa do título em alemão Celsus' Wahres Wort.

${ }^{8}$ Duas fontes indicam esse Celso: Galeno (ca. 129 - ca. 215 d.C.) e Luciano (ca. 125 - ca. 185 d.C.). Galeno menciona ter enviado uma carta a um "Celso o Epicureu" e Luciano inicia seu livro "Alexandre, o Falso Profeta" dizendo que dedica-o a um "Celso". Encontra-se a referência direta no trabalho de Luciano,
} 
não refletir tal afirmativa de Keim, o qual coloca Celso como um platônico eclético, que não era ao mesmo tempo um "epicurista completo", Keim afirma que é quase cego o estudioso que não percebe o amigo de Luciano no Celso do Discurso Verdadeiro (KEIM, 1873: 278).

Adentrando o século XX, há a retomada da recomposição do texto por Otto Glöckner (1924) e Robert Bader (1940), em grego. Os tradutores possuem preferência por, em paralelo com as tentativas de reconstruções, utilizar das diversas traduções do Contra Celso $^{10}$, justificando que se tornou amplamente aceita a ideia das omissões e abreviações de Orígenes em relação ao Discurso Verdadeiro. $\mathrm{Na}$ introdução dessas traduções ${ }^{11}$ do Discurso Verdadeiro e do Contra Celso, os autores se dedicam a exibir suas teorias sobre quem foi Celso.

em:LUCIAN.Alexander the False Prophet. In: LUCIAN.In Eight Volumes: Lucian vol. IV. Trad. A. M. Harmon. Harvard: Loeb, 1925.

${ }^{9}$ ORIGEN. Contra Celsum. Trad. Henry Chadwick. Cambridge: University Press, 2003, XXV.

${ }^{10}$ Das mais antigas às mais recentes, citemos algumas: ORIGEN. AgainstCelsus. Trad. James Bellamy. London: s.n., 1660 (inclui apenas os dois primeiros volumes); ORIGÉNE. Traité D’Origéne Contre Celse. Trad. Ellie Bouhéreau. Amsterdam: s.n., 1700; ORIGENES. OrigenesWerke. Trad. Paul Koetschau. Leipzig: s.n., 1899 (essa obra trata de outras de Orígenes e dos primeiros quatro volumes do Contra Celso); ORIGEN. Contra Celsum. Trad. Henry Chadwick. Cambridge: University Press, 2003 (a tradução de Henry Chadwick para o inglês é a mais utilizada nos dias atuais; foi feita em 1953, primeiramente, e revisada em 1965); ORIGENES. Contra Celso. Trad. Orlando dos Reis. São Paulo: Paulus, 2004.

${ }^{11}$ Temos conhecimento de cinco traduções do Discurso Verdadeiro, apesar de acesso a três delas: CELSE. Logos Alèthès. Trad. Louis Rougier. Paris: s.n., 1965 (francês); CELSUS. On the True Doctrine: A Discourse Against the Christians. Trad. Joseph Hoffmann. Oxford: University Press, 1987 (inglês); CELSO. El Discurso Verdadero Contra losCristianos. Madrid: Alianza, 2009 (espanhol). As duas restantes são: KELSOS. Die Wahrelehre. Trad. Albert 
Henry Chadwick(in ORIGEN, 2003: XXIV-XXVI) refuta as especulações sobre epicurismo de Keim e coloca sua opinião - baseandose no respeito aparente de Celso por Platão, por meio de partes da fonte - de que ele seria somente um platônico eclético; utiliza, em seguida, das referências de Keim a "duas dúzias de Celsos" nos três primeiros séculos para demonstrar, dessa maneira, que uma aproximação da real identidade de Celso se torna impossível. Posteriormente, conclui que Celso possuía afinidades claras com o médio platonismo e que é inconcebível que fosse um epicurista, afirmando que não podemos saber, na verdade, nada sobre o oponente de Orígenes se não o que o texto nos remete.

Joseph Hoffmann(in CELSUS, 1987: 30-31), em um tópico denominado "A Identidade de Celso", faz comparativos com um dos "Celsos" citados por Orígenes; em específico, o Celso do tempo do Imperador Adriano, que seria o mesmo escritor de vários tratados contra a magia. Em relação ao epicurismo, Hoffmann (apud WILKEN, 1987: 31) cita outro autor, Robert Wilken, que exprime que tachar Celso como epicurista é fazer a tarefa de criticá-lo como mais fácil. Entretanto, apesar da referência, tende a concordar em sua conclusão que a possibilidade de Celso ter sido o conhecido de Luciano não perde forças, podendo ele ter mudado seu viés filosófico para médio platonismo quando próximo de compor seu Discurso Verdadeiro (HOFFMANN in CELSUS, 1987: 32-33).

Wifstrand. Lund: C.W.K Greelups, 1942 (sueco); KELSOS. Die Wahre Lehre. Trad. Horace E. Lona. Freiburg: Herder, 2005. 
SerafínBodelón, na tradução mais recente, descreve que o Celso do Discurso Verdadeiro é o mesmo para o qual Luciano direciona seu trabalho; Bodelón articula que, para exercícios de retórica e combates ideológicos, o autor poderia recorrer a quaisquer ferramentas ao alcance: assim, Celso escolheria o médio-platonismo, pois, o mesmo era o viés filosófico mais utilizado pelos alvos de seu Discurso Verdadeiro, os cristãos (BODELÓN in CELSO, 2009: 18, 28-29).

A visão mais breve é de dicionário, escrita por Adalbert Hamman, que apresenta que ele foi um filósofo platônico eclético, de provável origem egípcia, que passou um tempo em Roma, se informando assim dos movimentos de ideias de sua época e que escreveu sua obra sob império de Marco Aurélio (de 161 a 180 d.C.) (HAMMAN, 2002: 278).

Expostas as diversas opiniões, percebe-se que as tendências mantêm-se ainda em conflito, entre um Celso platônico eclético e um epicurista: pelo lado platônico eclético, os autores recorrem ao fato de aparentar ser a opção que corresponde melhor à própria personalidade de Celso que o Discurso Verdadeiro reflete e se adequar às indicações e posteriores dúvidas de Orígenes em seu Contra Celso; pelo epicurista, por outro lado, têm-se as atestações que fontes próximas oferecem, propiciando maior autenticidade, porém, sem se encaixar realmente no que o texto nos passa. O único consenso seria o provável local de vida do autor: Alexandria. Essa atestação se produz por Celso ter conhecimento amplo das várias escolas filosóficas - algo verificável em seu trabalho.

A exibição do manuscrito de Celso segue uma proposta em que, primeiramente, deve-se descreditar a vida de Jesus e seus milagres para, 
posteriormente, prosseguir na desconstrução das doutrinas que por meio desses fatores se frutificaram. O autor, assim, analisa tanto os judeus quanto os cristãos, colocando os judeus como "viciados em magia, assim como suas escrituras mostram que Moisés era..." (CELSO, Discurso Verdadeiro, II, 64-66). Ataca, em seguida, o cristianismo e mostra que o mesmo nada mais é que uma seita dissidente, que baseia-se em uma religião que por si só não possui originalidade.

Na Introdução do Discurso Verdadeiro Contra os Cristãos, encontramos a seguinte passagem:

Quem não ouviu falar da fábula do nascimento de Jesus de uma virgem, ou as histórias de sua crucifixão e ressurreição? E por essas fábulas os Cristãos estão prontos para morrer - de fato, para morrer (CELSO, Discurso Verdadeiro, I, 37-40).

Celso, após expor algumas reflexões sobre o sigilo suspeito das seitas cristãs e seus clamores pela originalidade de seus mitos e doutrinas, critica o fanatismo dos cristãos, dispostos a seguir o que o Imperador Marco Aurélio chama de uma superstição irracional que recorre à morte por "pura revolta” (MARCO AURÉLIO, Meditações, XI, 3). Tais homens, por meio da prática de martírio, procuravam por reencenar o julgamento e morte de Jesus Cristo, buscando uma valorização maior desse episódio, em detrimento dos ensinamentos de Jesus como mestre sábio, que pregava a paz (THOMPSON, 2002: 50).

Ao falar sobre o nascimento de Jesus de uma virgem, Celso (II, 80-84) imagina um judeu - ou, quem sabe, um filósofo - que colocasse 
a seguinte pergunta a Jesus: "Não é verdade, bom senhor, que você fabricou a história do seu nascimento de uma virgem para aquietar os rumores sobre a verdadeira e execrável circunstância da sua origem?’”. Continuando sua exposição, articula que, na verdade, Jesus nasceu em uma cidade pobre de uma mulher que ganhava a vida tecendo, que engravidou de um soldado romano de nome Pantera, e foi acusada pelo marido carpinteiro de ser adúltera. Em sua desgraça, ela vagou para longe de casa, parindo a criança em silêncio e humilhação; após isso, conta que Jesus, tornando-se homem, seguiu até o Egito, contratado como operário, e lá aprende o uso da magia e utilizou-se disso para vangloriar-se perante seu povo (II, 85-97).

Nada de diferente, dessa forma, se faz de mitos passados, que são semelhantes. Para provar que o fato de Jesus reivindicar que era proveniente de uma concepção entre um deus e uma mortal era absurda, Celso (II, 160-165) aponta uma contraposição, atravésdos mitos dos gregos que atribuem nascimentos divinos a Perseu, Minos, dentre outros, que são igualmente evidências atestáveis de seus feitos heroicos em prol da humanidade e, certamente, não possuem menor plausibilidade do que a de Jesus.

Além de seu nascimento, outro fato importante é a ressurreição de Cristo. Celso opõe a tal afirmativa as seguintes atribuições:

Assumamos, presentemente, que ele previu sua ressurreição. Vocês são ignorantes das multidões que inventaram contos similares para desencaminhar ouvintes simplórios? É dito que Zalmoxis, servo de Pitágoras, convenceu os Ci- 
tianos $^{12}$ que ele ergueu-se dos mortos, tendo se ocultado em uma caverna por vários anos; e que tal Pitágoras na Itália! ou Rampsinito no Egito(CELSO, Discurso Verdadeiro, III, 235-242).

Possuímos, portanto, a tentativa de Celso de deslegitimar um fato que atraia multidões, algo mal recebido por Roma desde tempos anteriores à expansão como Império; adentramos, dessa forma, um outro âmbito da discussão: a religio e a superstitio. L. F. Janssen (1979:150) demonstra que a religio possuía papel principal na parte oficial da magistratura romana, enquanto que a superstitio deveria ser combatida como um inimigo do Império. O termo latim religio, inicialmente, expressava a ideia e a qualidade entre os latinos de ser precisos e escrupulosos em relação às práticas religiosas, que acabava por designar, também, os responsáveis pela escolha ritual adequada (AGNOLIN, 2013: 225). Em relação ao Império Romano, a religio oferecia uma fonte poderosa para legitimar decisões políticas; permeando todas as áreas da sociedade, as práticas religiosas fizeram parte da realidade cultural, extravasando um possível confinamento das mesmas a templos e festivais. Por meio de rituais, a comunicação com os deuses demonstrava publicamente esse ato de religar, que pressupunha que os mesmos participavam ativamente dos âmbitos social e político (RÜPKE, 2007: 4-7).

Em relação oposta à religio, asuperstitio significava, em associação à cives - cidadania -, o ato de se sujeitar o bem comum em prol do indivíduo. Antes do cristianismo, por exemplo, os cultos báquicos foram

${ }^{12}$ Provenientes da Cítia. 
reprimidos no séc. II a.C. na res publica romana, quando os iniciados desses ritos foram perseguidos e mortos, já que essa manifestação religiosa estava atraindo inúmeros aderentes para práticas que as autoridades religiosas da época julgaram como ilícitas e não cumpridoras dos requisitos de observância pública. Nas palavras de Janssen (1979: 138), superstitio era como uma "doença infecciosa", que espalhava-se mais e mais; por meio de sua própria forma contagiosa, tornou-se um verdadeiro risco à humanidade. Como observamos, em seguida, nas cartas do Governador Plínio o Jovem (X, 96, 9) ao Imperador Trajano, no início do séc. II d.C., o cristianismo era visto como uma perigosa contagio infecção, influente - que disseminou-se por várias vilas e distritos rurais de sua província, trazendo consigo a deserção de diversos templos e dos ritos sagrados.

A partir do exposto anteriormente, notamos que os cristãos em sua ligação com o Império não possuíam vinculação real; a vida e alma de um cristão não pertenciam ao Imperador, mas a Cristo. Eles eram, verdadeiramente, cristãos, não romanos. Ao negar os cultos e sacrifícios aos deuses romanos, repudiando sua existência, os cristãos recusavam o cerne da cidadania romana; ao professar Cristo como seu guia, eles renunciavam a participação no Império e, consequentemente, tornavam-se inimigos da res publica. A crença cristã era, certamente, uma superstitio autêntica: prometia felicidade eterna e a participação em um Reino dos Céus aos seus seguidores, se eles decidissem seguir Jesus; os governadores terrenos pereceriam perante o fogo e espada, e apenas aqueles que colocassem sua fé em Cristo sobreviveriam, tornando-se superstes - 
sobreviventes. E após isso, no fim dos tempos, Jesus retornaria à Terra para fundar seu eterno reino de paz (JANSSEN, 1979: 153).

Suetônio, em seu manuscrito Vida dos Doze Césares, em um tópico que descreve o governo de Nero, possui uma passagem que ratifica o que Janssen intenta demonstrar:

Sob seu governo, várias práticas foram reprovadas e sujeitas a restrições e muitas novas leis foram sancionadas. [...] Punições foram impostas contra os Cristãos - seguidores de uma nova e perigosa superstição (SUETÔNIO, Vida dos Doze Césares, Nero, 16, 2, grifo nosso).

Em latim, "perigosa superstição" consta como maleficasuperstitio. O que ligava a superstitio aos cristãos eram as acusações de prática de magia; tais atos foram sempre reprovados e punidos como ofensas ao Império, principalmente quando a prática de profetizar a morte era direcionada à família imperial e ao Imperador (JANSSEN, 1979: 157).

Em relação a este assunto, AndrzejWypustek (1997: 280), em seu artigo nomeado "Magia, Montanismo, Perpétua, e a Perseguição dos Severos" $" 13$, levanta o debate acerca do qual montanistas seriam tachados como praticantes de magia - eles eram, na época, ainda uma seita cristã, que seria futuramente relegada à heresia. $\mathrm{O}$ ato de profetizar aflições vindouras se torna uma afronta aos olhos de governantes do período dos Severos, uma vez que interferiam no âmbito político. Montanistas compilaram vários escritos com esse teor profético, rotulados como escrita

\footnotetext{
${ }^{13}$ WYPUSTEK, Andrzej. Magic, Montanism, Perpetua, and the Severan Persecution. VigiliaeChristianae, Leiden, v. 51, n. 3, p. 276-297, 1997.
} 
mágica, algo combatido no período de Septímio Severo. De acordo com pagãos, como apresenta o autor, o nome de Cristo era utilizado em fórmulas mágicas, com intuito de praticar exorcismos, curas, adivinhações e criar proteções mágicas. Em conjunto a isso, os mártires montanistas eram vistos como pessoas que retinham força sobre-humana; todos esses fatores implicariam em uma visão de que os cristãos montanistas eram praticantes de feitiçaria (WYPUSTEK, 1997: 282-283). É o que corroboramos com uma das alegações de Celso, quando disserta que

Os Cristãos dizem poder adquirir alguma forma de poder ao pronunciar nomes de demônios, ou ao dizer certos encantamentos, sempre incorporando o nome de Jesus e uma curta história sobre ele na fórmula. Até essa prática é dada como velha: o próprio Jesus era visto fazendo milagres utilizando-se de magia e encantamentos. Ele sabia que outros segui-lo-iam nessas práticas, contudo ele pareceu expulsar de sua sociedade aqueles que o fizeram. Talvez essa seja a origem da hipocrisia pela qual os Cristãos são tão bem conhecidos: estava ele certo de afastá-los por copiá-lo? Sendo ele mesmo culpado de feitiçaria ele não possuía razão para acusar outros, nem eles poderiam ser vistos como homens ruins por seguir seu líder (CELSO, Discurso Verdadeiro, I, 53-54).

Com uma releitura do provável decreto ${ }^{14}$ de Septímio Severo contra as práticas de proselitismo cristãs e judaicas, Wypustek (1997: 285)

\footnotetext{
${ }^{14}$ Entre dois artigos correlacionados, há a divisão - entre as autoridades no assunto - de que: 1) T. D. Barnes expressa que as fontes analisadas para responder tais perguntas (Eusébio de Cesaréia e Sulpício Severo) falsificaram acontecimentos - ou foram alteradas posteriormente - para legitimar ações anticristãs de Imperadores passados (Septímio Severo, no caso desse debate), demonstrando assim as repressões dos ditos pagãos contra os cristãos; 2) W. H. C. Frend,
} 
propõe que, ao invés da proibição das conversões de pagãos às religiões citadas, a chave para a compreensão desse decreto é percebê-lo como um ato de supressão das práticas de magia e profecia, que se tornam, consequentemente, formas de superstições que acrescentam seguidores às religiões citadas; ademais, diferenciar acusações entre judeus e cristãos até meados do III séc. d.C. não é visto como uma afirmativa plausível, sendo a maioria destas perseguições ocasionadas principalmente por práticas de magia.

Como último ponto marcante de seus milagres, temos a apoteose de Jesus. Celso sobre isso, denota que:

Ao nascer, ele partilhou das fragilidades da carne que os próprios Cristãos consideram abomináveis. Eles dissertam, entretanto, que ele deixou de lado essa carne em favor de uma outra, e assim tornou-se um deus. Mas se apoteose é a marca de divindade, porque não então Asclépio, Dionísio, ou Héracles, cujas histórias são muito mais antigas? Eu ouvi um Cristão ridicularizar aqueles em Creta que mostram a turistas a tumba de Zeus, dizendo que esses Cretanos não possuem razão para fazer o que fazem. Talvez o seja; ainda

por outro lado, ressalta que o período sob governo de Septímio Severo experimenta várias perseguições aos cristãos, as quais só cessam quando o Imperador parte em expedição para reconquistar o que seria, no tempo presente, as Terras Baixas na Escócia. Vale lembrar que as obras de Eusébio e Sulpício (História Eclesiástica e História Sacra, respectivamente) são feitas contemporâneo a ou posterior ao Édito de Milão, em 313 d.C, que torna a religião cristã como legal ante o Império Romano. Ver: BARNES, T. D. Legislation Against the Christians. The Journal of Roman Studies, Oxford, vol. 58, parts 1 and 2,p. 32-50, 1968; FREND, W. H. C. Open Questions Concerning the Christians and the Roman Empire in the Age of the Severi.Journal of Theological Studies, Oxford, vol. XXV, part 2, p. 333-351 October 1974. 
assim os Cristãos baseiam sua fé em um que ergue-se de uma tumba (CELSO,Discurso Verdadeiro, IV, 115-126).

Como intenta demonstrar Celso em sua obra, todos os fatos expostos por si pretendem evidenciar aquilo que propalava o cristianismo em sua época: a fácil aderência de suas falácias nas mentes daqueles que são ignorantes, estúpidos, deseducados, dentre outros. $\mathrm{O}$ ato de se admitir que tais pessoas eram dignas do seu deus demonstrava a habilidade cristã de convencer apenas aos tolos, desonrosos e ineptos (CELSO, Discurso Verdadeiro, IV, 130-136).Firmamo-nos conforme relata Dion Cássio em sua História Romana, escrita no III séc. d.C., por meio da qual podemos perceber o desafeto à magia como algo muito anterior e que já era visto como um problema a ser endereçado com importância, através da citação a seguir de Mecenas ao Imperador Otávio Augusto:

Profetizar, para se ter certeza, é uma arte necessária, e você deveria de qualquer forma indicar alguns homens para serem adivinhos e áugures, para os quais aqueles que querem consulta-los em qualquer assunto recorrerão; mas de forma alguma devem haver praticantes da magia. Pois tais homens, dizendo a verdade às vezes, mas geralmente mentiras, frequentemente encorajam muitos a tentarem revoluções(DION CÁSSIO, História Romana, LII, 36, 2, grifo nosso).

Figura central da qual o próprio movimento religioso toma o nome, para os cristãos primitivos Jesus Cristo figurou como realizador de milagres e tornou-se um exemplo, tanto de grande sábio, quanto de alguém que lidou com a morte de uma maneira que os mesmos julgavam como gloriosa. Celso, analisando tais histórias sobre esse líder, percebeu 
que tentar demonstrar que esses milagres não passavam de práticas de magia e que muitos outros nomes conhecidos já haviam empreendido tarefas e feitos de equivalente grandiosidade propiciaria a tarefa de deslegitimá-lo e, similarmente, àqueles que seguiam a sua doutrina, fazendo sua obra tornar-se, dessa forma - propositalmente ou não -, um documento que justificasse as perseguições e a rotulação de superstitio quanto ao cristianismo em sua época.

\section{Fontes}

CELSE. Discours vrai contre les Chrétiens. Tradução de Louis Rougier. Paris: Jean-Jacques Pauvert, 1965.

CELSO. El Discurso Verdadero Contra losCristianos. Tradução de Serafín Bodelón. Madrid: Alianza, 2009.

CELSUS; PORPHYRY; JULIAN. Arguments of Celsus, Porphyry, and the Emperor Julian, Against the Christians; also extracts from DiodorusSiculus, Josephus, and Tacitus, relating to the Jews. Tradução de Nathaniel Lardner. London: Thomas Rodd, 1830.

CELSUS. On the True Doctrine: A Discourse Against the Christians. Tradução de Joseph Hoffmann. Oxford: University Press, 1987.

DIO CASSIUS. Roman History: In Nine Volumes: vol. VI. Tradução de Earnest Cary. London: William Heinemann, 1955.

KELSOS. Die Wahre Lehre. Tradução de Albert Wifstrand. Lund: C.W.K Greelups, 1942.

KELSOS. Die WahreLehre. Tradução deHorace E. Lona. Freiburg: Herder, 2005. 
LUCIAN. In Eight Volumes: Lucian vol. IV. Tradução de A. M. Harmon. Harvard: Loeb, 1925.

MARCUS AURELIUS. Meditations. Tradução de Martin Hammond. London: PenguinClassics, 2006.

ORIGEN. Contra Celsum. Tradução de Henry Chadwick. Cambridge: University Press, 2003.

ORÍGENES. Contra Celso. Tradução de Orlando dos Reis. São Paulo: Paulus, 2004.

SUETONIUS. Lives of the Caesars. Tradução de Catharine Edwards. Oxford: University Press, 2008.

\section{Bibliografia}

AGNOLIN, Adone. História das Religiões: Perspectiva históricocomparativa. São Paulo: Paulinas, 2013.

BARNES, T. D. Legislation Against the Christians. The Journal of Roman Studies, Cambridge, vol. 58, parts 1 and 2, p. 32-50, 1968.

BEARE, Frank W. Books and Publication in the Ancient World.University of Toronto Quarterly, Toronto, v. 14, issue 2, p. 150167, 1945.

JANSSEN, L. F. 'Superstitio' and the Persecution of the Christians. VigiliaeChristianae, Leiden, v. 33, n. 2, p. 131-159, jun. 1979.

WYPUSTEK, Andrzej. Magic, Montanism, Perpetua, and the Severan Persecution. Vigiliae Christianae, Leiden, v. 51, n. 3, p. 276-297, 1997.

BRUHL, Charles. La Polémique de Celse Contre le Christianisme. Strasbourg: Frédéric-Charles Heitz, 1844.

DI BERARDINO, Angelo (org.). Dicionário Patrístico e de Antiguidades Cristãs. Petrópolis: Vozes \& Paulus, 2002. 
Cadernos de Clio, Curitiba, v. 7, nº. 2, 2016

KEIM, Theodor. Celsus' Wahres Wort: Aeltestestreitschrift Weltanschauung gegen das Christentum vom Jahr 178 n.Chr.. Zürich: s.n., 1873.

PELAGAUD, Elisée. Un conservateur au second sécle. Lyon: LouisBenoit Perrin \& Alfred-Louis Perrin, 1878.

RÜPKE, Jörg. Roman Religion - Religions of Rome. In: (ed.). A Companion to Roman Religion. Oxford: Blackwell, 2007. p. 1-9.

Recebido em: 08/10/2016 Aceito em: 07/02/2017 